\title{
Preparation of Mesoporous Silica Uniformly Coated with Titania and Its Application to Hydrodesulfurization Catalyst
}

\author{
Haruka SATAKE ${ }^{* 1}$, Masaki OKAMOTO ${ }^{* 1 \dagger}{ }^{\dagger}$, Yasuyuki SAKAYORI ${ }^{2}$, Syota FURUDERA ${ }^{* 2}$, \\ Takeshi KUBOTA ${ }^{* 2}$ and Hiroyuki SEKI*3
}

(Received September 28, 2016)

\begin{abstract}
Titania coating of mesoporous silicas (MSs) with different pore size was performed several times under thoroughly dried circumstances. When the pore size was $3 \mathrm{~nm}$, the pore-plugging took place by only one time coating. On the other hand, for the pore size of $7 \mathrm{~nm}$, a uniform coating with titania layer could be achieved until three time coating, and for that of $10 \mathrm{~nm}$, the uniform coating without pore-plugging was obtained even after five time coating. These observations could be explained by the difference in the curvature of the silica pore walls. From various analyses and characterization, it was found that the titania coating was uniform and that three time coating was needed to coat all the silica walls and then possible coating mechanism was proposed.

The MSs coated with titania were applied as the support of Mo catalyst for hydrodesulfurization (HDS) of sulfur-containing aromatics. The effect of titania coating on the dibenzothiophene HDS was not significant, but positive increase in activity was observed for 4,6-dimethyldibenzothiophene HDS. This increase was due to the enhancement of hydrogenation ability, in agreement with the results from the naphthalene hydrogenation. Moreover, it was found the formation of three-dimensional pores is very useful to increase the HDS activity.

チタンアルコキシドを原料とし, 細孔径が異なるメソポーラスシリカのチタニアコーテイングを徹底的に水分を除去した条件下で数回 行った。細孔径が $3 \mathrm{~nm}$ の場合, 1回のコーテイングで細孔閉塞が起きた。一方, $7 \mathrm{~nm}$ では3回のコーテイングまで,10 nmでは5回コー テイングでも細孔の閉塞は見られなかったっこのような違いは,シリカ壁の湾曲率の違いで説明することができた。種々の分析およびキャ ラクタリゼーションから, チタニアはシリカ細孔内に均一に分布し, 3回コーテイングを行う事で, 細孔全体を覆うことがわかった。そして, チタニア膜形成機構を提案した。このようにして調製したチタニアコーテイングメソポーラスシリカを担体とし，モリブデンを担持した触 媒の脱硫活性を評価した。ジベンゾチオフェンの脱硫においては, チタニアコーテイングの影響が見られなかったが, 4,6-ジメチルジ ベンゾチオフェンに対しては高い脱硫活性を示した。これは, チタニアコーテイングにより触媒の水素化活性が向上したためで, ナフ夕 レンの水素化実験結果と一致した。更に, メソポーラスシリカ細孔を三次元化することで, 脱硫活性を飛躍的に向上することができた。
\end{abstract}

\section{Key Words}

Mesoporous silica, Titania coating, Hydrodesulfurization, Three-dimensional pore

\section{Introduction}

Titania is widely used as white pigments, photocatalysts ${ }^{1)}$, catalyst supports ${ }^{2)}$ and so on. For use of catalysts or catalyst supports, high surface area is suitable to show a high catalytic activity. Since titania is generally non-porous, its surface area is low $\left(<200 \mathrm{~m}^{2} \mathrm{~g}^{-1}\right)$ even when the particles are small. Recently, mesoporous

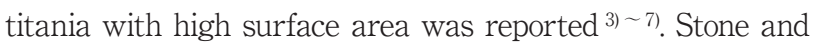
Davis have prepared mesoporous titania with high surface area $\left(712 \mathrm{~m}^{2} \mathrm{~g}^{-1}\right)$, but the calcination decreased the surface area to $90 \mathrm{~m}^{2} \mathrm{~g}^{-13)}$. For calcined mesoporous titanias, mesopore structure was not ordered and the surface area

\footnotetext{
$※ 1$ Department of Chemical Science and Engineering, School of Materials and Chemical Technology,

Tokyo Institute of Technology

2-12-1-E4-4, Ookayama, Meguro-ku, Tokyo 152-8552, Japan

※2 Department of Materials Science, Shimane University
※3 Central Technical Research Laboratory, JX Nippon Oil \& Energy Co. 8, Chidori-cho, Naka-ku, Yokohama-shi, Kanagawa 231-0815, Japan
$\dagger \quad$ Corresponding author: okamoto@cap.mac.titech.ac.jp 1060, Nishikawatsu-cho, Matsue-shi, Shimane 690-8504, Japan 
was lower than $467 \mathrm{~m}^{2} \mathrm{~g}^{-14}$ ). On the other hand, in the case of silica, ordered mesoporous materials have been reported, and they have a larger surface area than mesoporous titania $^{8)}{ }^{9 !}$.

To prepare titania with high surface area, many researchers have reported the coating of mesopore walls of the ordered mesoporous silica with titania layers ${ }^{10)} \sim 15$ ). Vradman and co-workers reported that titanium butoxide as a titania source was added to a suspension of mesoporous silica particles in $\mathrm{n}$-decane to form titania nanocrystals inside mesopores ${ }^{10}{ }^{11}$. Perathoner et al. have used titanium isopropoxide as a titania source and performed the reaction of hydroxyl groups on mesoporous silica surface with titanium isopropoxide in various anhydrous organic solvents ${ }^{12)}$. They concluded that a kind of solvents did not affect structure of titania formed in mesoporous silica and that mesopore walls were coated with titania when the titania content was below $12 \mathrm{wt} \%$.

Multiple coating of mesoporous silicas with titania was also reported. Yan et al. used sol-gel modification of mesopore walls of SBA-15 (pore size is $8.5 \mathrm{~nm}$ ) with titanium tetraisopropoxide and titanium tetrachloride to coat the pore walls with titania and the coating procedure was repeated three times ${ }^{14}$. The isotherms of nitrogen adsorption-desorption showed declined steps. This indicates that mesopore size was not uniform. Zhang et al. had also reported multiple coating with titania. The mesopore walls of SBA-15 with a diameter of ca. $7 \mathrm{~nm}$ were coated with titanium isopropoxide in iso-propanol and the coating procedure was repeated up to 4 times ${ }^{15}$. The nitrogen adsorption-desorption analysis revealed titania coating to be ununiform after three-time coating. They concluded that 2 nm or smaller $\mathrm{TiO}_{2}$ domains which cover only partially the silica surface.

To our best knowledge relating to the titania coating of mesoporous silica, there has been no report to show the coating of pore walls with uniform titania layers; the pores were plugged with small titania particles and/or titania particles were formed independently outside mesoporous silica. We supposed that a small pore size might lead to the formation of Ti-O-Ti bridges across the diameter to form small titania particles in the pores. The effect of the pore size, therefore, was examined in the present study. Also, to uniformly coat the mesopore walls with titania layers, the solvent selection and the pretreatment of mesoporous silica should be careful, avoiding moisture during the coating. Thus, in this work, a dry toluene solvent was chosen and mesoporous silica was dried thoroughly before coating.

For the hydrodesulfurization (HDS) catalysts, titania is preferably incorporated into alumina or silica supports as complex oxides since the catalysts with titania give a higher HDS activity than those without titania ${ }^{16)} \sim 20$ ). In this study, the titania-coated mesoporous silicas were applied to catalyst supports for HDS of sulfur-containing aromatics. Titania-coated mesoporous silicas as a support of HDS catalyst was previously reported by other groups ${ }^{21)}{ }^{22)}$. However, their preparation method could not necessarily exclude the possibility of $\mathrm{TiO}_{2}$ aggregation on the surface of mesoporous materials. This report is the first investigation of the support effect of titania on $\mathrm{MoS}_{2}$ catalyst using titania coated mesoporous silica materials.

Moreover, when one dimensional mesoporous silicas such as SBA-15 are used as catalyst supports, they do not seem enough suitable to obtain a high diffusivity of reactants and products through mesopores. We have reported the formation of three dimensional network of mesopores in SBA-15 and the enhancement of catalytic activity of aminopropyl group-grafted SBA15 for Knoevenagel condensation of ethyl cyanoacetate and acetone due to a high diffusivity ${ }^{23)}$. Silica can be decomposed by the reaction with DMC catalyzed by alkali metal salts ${ }^{24)}{ }^{25}$; when the alkali metal salt was impregnated inside mesopores, the areas around the loaded catalyst were decomposed by DMC. Since silica decomposition reaction did not proceed at areas where a small amount of the catalyst existed, slightly uneven distribution of the impregnated catalyst on the pore walls resulted in formation of interconnected pores in patches. For the HDS catalysts, the DMC-treated mesoporous silicas were used as catalyst supports to increase diffusivities of reactants and products.

\section{Experimental}

\subsection{Preparation of mesoporous silicas}

Three mesoporous silicas (MSs) with pores different in size (3, 7 and $10 \mathrm{~nm}$ ) were prepared. Silica having mesopores with the diameter of ca. $7 \mathrm{~nm}$ was prepared as the following method. Triblock copolymer (Pluronic P-123 $\mathrm{EO}_{20} \mathrm{PO}_{70} \mathrm{EO}_{20}, 4 \mathrm{~g}$, Aldrich) was dissolved in water (81.2 g). After addition of hydrochloric acid (6 M, $40 \mathrm{~mL}$, Kanto Chemical Co.) to the solution, tetraethoxysilane $(8.54 \mathrm{~g}$, Tokyo Chemical Industry Co.) was added dropwisely, stirred at $35^{\circ} \mathrm{C}$ for $24 \mathrm{~h}$, and settled for $48 \mathrm{~h}$. The white precipitate was dried at $100^{\circ} \mathrm{C}$ for $2 \mathrm{~h}$ and calcined at $550^{\circ} \mathrm{C}$ for $4 \mathrm{~h}$ to remove the surfactant. To expand the mesopore size, trimethylbenzene were added to the synthesis gel. The pore size of the obtained mesoporous silica was ca. $10 \mathrm{~nm}$.

Silica having mesopores with the pore size of $3 \mathrm{~nm}$ was prepared using cetyltrimethylammonium bromide (Tokyo Chemical Industry Co.) as the surfactant. The 
aqueous solution (281 $\mathrm{mL}$ ) of the surfactant (31.1 g), sodium silicate (27.3 g, Kishida Chemical Co.) and sulfuric acid (2.8 g, Kanto Chemical Co.) were settled at $90^{\circ} \mathrm{C}$ for $96 \mathrm{~h}$. The obtained precipitate was dried and calcined at $550{ }^{\circ} \mathrm{C}$ for 4 h. The prepared mesoporous silica was shown as MS- $x$ ( $x$ is pore size).

According to the procedure in our previous study ${ }^{23)}$, the formation of three-dimensional network of mesopores in MS-7 was performed. Channels interconnected between neighboring pores were formed by the following method. Dried MS-7 (1 g) was added to deionized water (3 mL) in which $\mathrm{KCl}$ (0.01 g, Kanto Chemical Co.) was dissolved. The mixture was settled overnight, dried via vacuum before a further $1 \mathrm{~mL}$ of water was added to introduce the salt loaded on the external surface of the MS-7 particles into the pores. After settling overnight and drying via vacuum, the white powder was dried at $200^{\circ} \mathrm{C}$ in an oven overnight. After loading $\mathrm{KCl}$, the powder $(0.5 \mathrm{~g})$ was placed into a fixed-bed flow reactor, dimethyl carbonate (DMC, $96 \mathrm{kPa}$, Kanto Chemical Co.) was fed into the reactor at $370{ }^{\circ} \mathrm{C}$ following heat treatment at $370{ }^{\circ} \mathrm{C}$ for $1 \mathrm{~h}$. The proportion of decomposition was calculated from the yield of tetramethoxysilane as a decomposition product, which was analysed using gas chromatography (GC). The proportion of silica decomposition was controlled at 30\% in MS-7. To remove the potassium ion, the DMC-treated MS-7 was stirred in an aqueous $\mathrm{HNO}_{3}$ solution $(0.1 \mathrm{M}, 30 \mathrm{~mL}$, Kanto Chemical Co.) overnight, washed thoroughly with water and dried at $150^{\circ} \mathrm{C}$ overnight. Finally, the treated mesoporous silica was calcined at $400{ }^{\circ} \mathrm{C}$ for $4 \mathrm{~h}$ to remove carbon deposits formed by DMC self-decomposition.

\subsection{Coating mesopore walls with titania layers}

The mesoporous silica (MS) was died at $250^{\circ} \mathrm{C}$ for $3 \mathrm{~h}$ in vacuum. The dried MS (1 g) was dispersed in a dry toluene (130 g, Kanto Chemical Co.) by sonication. Titanium tetraisopropoxide $(\mathrm{Ti} / \mathrm{Si}=0.30$, Wako Pure Chemical Industries) in a dry toluene (17 g) was added dropwisely to the suspension under dry $\mathrm{N}_{2}$, and the mixture was stirred for $20 \mathrm{~h}$ and washed. The coated silica was dried at $140{ }^{\circ} \mathrm{C}$ for $2 \mathrm{~h}$ and calcined at $550^{\circ} \mathrm{C}$ for $6 \mathrm{~h}$ to remove the propoxy groups. This coating procedure was repeated up to 5 times.

\subsection{Characterization of mesoporous silicas}

Nitrogen adsorption-desorption measurements were carried out on Bellsorp mini (Bel Japan). Samples were prepared by drying at $300^{\circ} \mathrm{C}$ for $3 \mathrm{~h}$ under a dry nitrogen stream before analysis. The pore size distributions were calculated from the adsorption isotherms.

The elemental analysis was performed using an inductively coupled plasma-optical emission spectrometer (ICP-OES) Prodigy ICP (Leeman Labs, Inc.). The samples $(0.01 \mathrm{~g})$ were added to a mixture $(1 \mathrm{~mL})$ of $26.5 \%$ hydrochloric acid, $21 \%$ sulfuric acid and $3 \%$ hydrofluoric acid, and heated at $150^{\circ} \mathrm{C}$ for $6 \mathrm{~h}$ in an autoclave to dissolve the sample completely.

The amount of silanol groups was estimated by dehydration of silanol groups using a thermogravimetric analyzer TGA-50 (Shimadzu Co.). The mesoporous silica was heated to $900{ }^{\circ} \mathrm{C}$ at $10^{\circ} \mathrm{C} \mathrm{min}{ }^{-1}$ of increasing rate of the temperature, and the temperature was kept for $1 \mathrm{~h}$. From the weight loss due to water formation, the amount of silanol groups was calculated.

Transmission electron microscopy (TEM) images of MSs coated with titania were acquired using a HD2700 instrument (Hitachi High-Technologies Co.) operated at an accelerating voltage of $200 \mathrm{kV}$ equipped with an energy dispersive X-ray (EDX) spectrometer. Before TEM observation, the mesoporous silica was etched by a focused ion beam (FIB) using a FB-2100 (Hitachi High-Technologies Co.) operated at an accelerating voltage of $40 \mathrm{kV}$ to make the sample thickness to be ca. $100 \mathrm{~nm}$.

Temperature-programmed desorption (TPD) of ammonia was performed using a multitask TPD apparatus (Bel Japan). Samples were prepared by heating at $500^{\circ} \mathrm{C}$ for $1 \mathrm{~h}$, exposure to ammonia at $100^{\circ} \mathrm{C}$ for $40 \mathrm{~min}$, and treatment in a vacuum at $100^{\circ} \mathrm{C}$ for $20 \mathrm{~min}$ before the measurement of the desorbed ammonia amount. The increasing rate of the temperature was $10^{\circ} \mathrm{C} \mathrm{min}$.

UV-Vis measurements were performed in the diffuse reflectance mode. A V-650 UV-Vis spectrophotometer (JASCO) equipped with an ISV-722 integrating sphere (JASCO) was used. The sample powders were put into a quartz cell and measured.

X-ray diffraction (XRD) patterns were obtained with a MiniFlex diffractometer (Rigaku Co.) using $\mathrm{Cu} \mathrm{K \alpha}$ radiation.

\subsection{Mo catalyst preparation}

Mo oxide catalysts supported on the synthesized mesoporous materials $\left(\mathrm{MoO}_{3}\right.$ /support) were prepared by a conventional impregnation method using $\left(\mathrm{NH}_{4}\right)_{6} \mathrm{Mo}_{7} \mathrm{O}_{24} \cdot 4 \mathrm{H}_{2} \mathrm{O}$ (AHM) as precursor ${ }^{26)} 27$. The support was impregnated with a solution of AHM, followed by evaporation of the impregnation solution at ca. $80^{\circ} \mathrm{C}$ for $5 \mathrm{~h}$. Then, the catalyst was dried at $100^{\circ} \mathrm{C}$ for $16 \mathrm{~h}$. The catalyst was calcined at $500{ }^{\circ} \mathrm{C}$ for $5 \mathrm{~h}$ in air. The Mo loading was fixed at $10 \mathrm{wt} \%$ $\mathrm{MoO}_{3}$.

The $\mathrm{MoO}_{3} /$ support catalyst thus prepared was presulfided at $350{ }^{\circ} \mathrm{C}$ for $3 \mathrm{~h}$ in a $10 \% \mathrm{H}_{2} \mathrm{~S} / \mathrm{H}_{2}$ flow at an 
atmospheric pressure.

\subsection{Catalytic HDS and HYD reaction}

The HDS reaction of dibenzothiophene (DBT) and 4,6-dimethyl-dibenzothiophene (4,6-DMDBT) was carried out by batch mode using an autoclave reactor ${ }^{26)}$. The sulfided catalyst (ca. $0.1 \mathrm{~g}$ ) was suspended in a reactant solution (1.0 wt\% DBT or $0.5 \mathrm{wt} \%$ 4,6-DMDBT solved in tetrahydronaphtalene (tetralin), $20 \mathrm{~mL}$ ) in a glove bag filled with $\mathrm{N}_{2}$ to avoid contact with air. The suspension was transferred to an autoclave in the glove bag. The HDS reaction was carried out at $280^{\circ} \mathrm{C}$ for $\mathrm{DBT}$ and $330^{\circ} \mathrm{C}$ for 4,6-DMDBT, respectively. The initial $\mathrm{H}_{2}$ pressure was 2.0 $\mathrm{MPa}$ at room temperature and the reaction time was $3 \mathrm{~h}$.

In order to understand the reaction mechanism due to the interaction between $\mathrm{MoS}_{2}$ and the support, naphthalene hydrogenation (HYD) reaction was carried out by the same procedure as above using a reactant solution (1.0 wt\% naphthalene solved in n-decane, $50 \mathrm{~mL}$ ) at $300^{\circ} \mathrm{C}$.

The reactant and products were analyzed by a gas chromatography equipped with an FID detector (GC-14A, Shimadzu). A UA-5 column (Frontier Lab, $30 \mathrm{~m}$ x $0.25 \mathrm{~mm}$ ) was used for the analysis of DBT $\left(70-250^{\circ} \mathrm{C}, 10^{\circ} \mathrm{C} \mathrm{min}^{-1}\right)$ and 4,6-DMDBT $\left(130-330^{\circ} \mathrm{C}, 10^{\circ} \mathrm{C} \mathrm{min}^{-1}\right)$, respectively. The conversion of DBT and 4,6-DMDBT and naphthalene was calculated from the decreased amount of the reactant.

\section{Results and discussion}

3.1 Coating mesopore walls of various mesoporous silicas with titania layers

The effect of mesopore size on coating of mesopore walls with titania layers was examined. Fig. 1 shows nitrogen adsorption-desorption isotherms of mesoporous silicas and pore size distributions. In the isotherms of uncoated mesoporous silicas, there were steep steps around $0.35,0.65$ and 0.75 of $p / p_{0}$. This indicates uniform size of mesopores. After coating mesopore walls with titania, the amount of nitrogen adsorbed and the pore size decreased, i.e. titania was incorporated into the pores. The steps in the isotherms of MS-7 and MS-10 were still steep. For the pore size of $3 \mathrm{~nm}$ (MS-3), however, a step was declined, and the titania coating slightly broadened the peak of the pore size distribution of MS-3 as shown in Fig. 1(b), indicating that the pore size was not uniform. These results showed the pore size larger than $7 \mathrm{~nm}$ is necessary for the uniform coating. When drying of MS-7 was not enough (heated at $140^{\circ} \mathrm{C}$ for $3 \mathrm{~h}$ ), the leaning of this step was observed, indicating that thorough drying of the silica is required for the uniform coating.

MS-7 and MS-10 were coated with titania up to five times, and the results are shown in Figs. 2 and 3, respectively. For both samples, the pore size decreased with an increase of the number of coating times. In the isotherms of MS-7 after coating over four times, the steps were slightly declined. This suggests that mesopore walls were not uniformly coated with titania after four-time coating. On the other hand, the isotherms of MS-10 coated with titania showed the uniformity even after five-time coating.

The results of the elemental and structural analyses of MS-7 and MS-10 after multiple coating are summarized in Table 1. The ratio of $\mathrm{Ti} / \mathrm{Si}$ increased with the number of coating times, and pore volume decreased. Fig. 4 shows the effect of the number of coating times on $\mathrm{Ti} / \mathrm{Si}$ ratio of MS-7 and MS-10 coated with titania. The Ti/Si ratios were proportional to the number of coating times, indicating that the amount of titania coated one time was constant. The increments in titanium amount at each coating step,
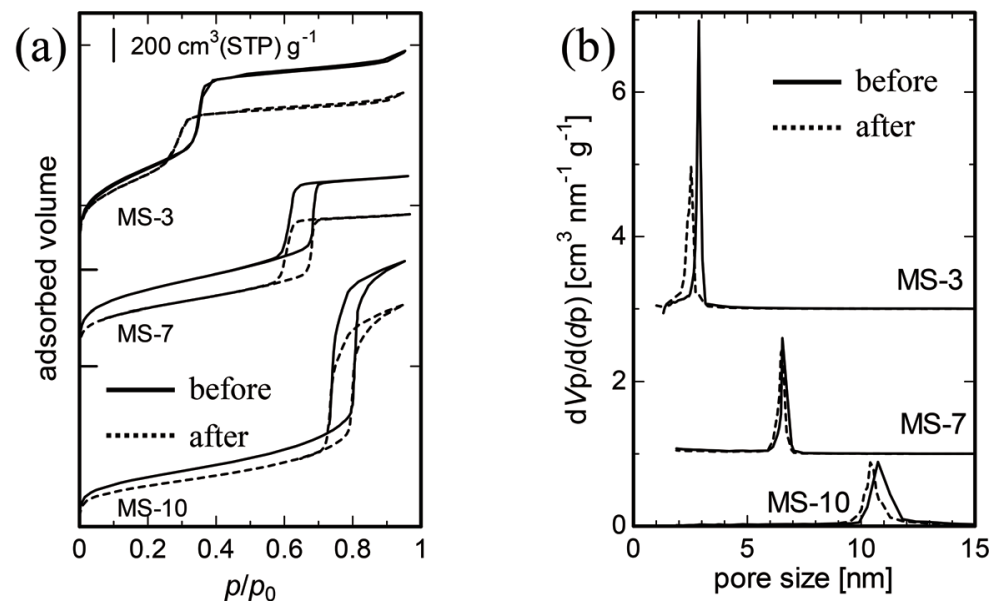

Fig. 1 Nitrogen adsorption-desorption isotherms (a) and pore size distributions (b) before and after one time coating with titania for mesoporous silicas with different pore sizes (MS-3, MS-7, MS-10) 

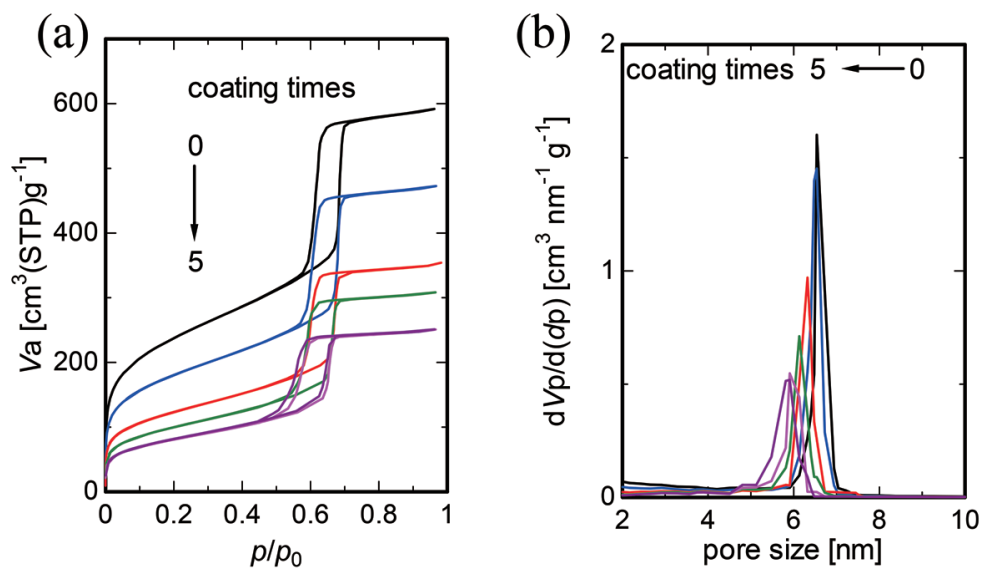

Fig. 2 Nitrogen adsorption-desorption isotherms (a) and pore size distributions (b) for MS-7 with different coating times
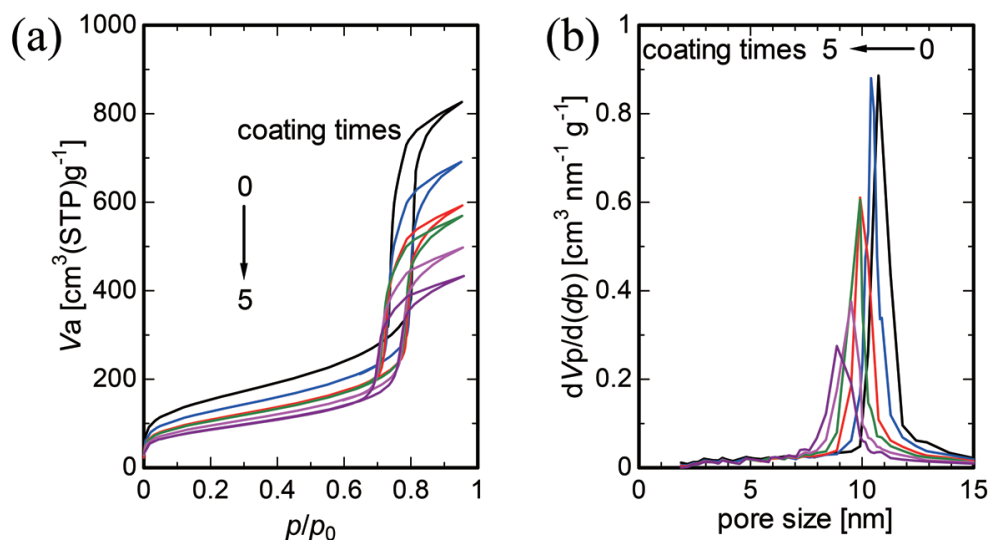

Fig. 3 Nitrogen adsorption-desorption isotherms (a) and pore size distributions (b) for MS-10 with different coating times

Table 1 Elemental and structural analyses for MS-7 and MS-10 after titania coating

\begin{tabular}{ccccc}
\hline $\begin{array}{c}\text { Coating } \\
\text { times }\end{array}$ & $\begin{array}{c}\mathrm{Ti} / \mathrm{Si} \\
(\mathrm{mol} / \mathrm{mol})\end{array}$ & $\begin{array}{c}\text { Pore volume } \\
{\left[\mathrm{cm}^{3} \mathrm{~g}^{-1}\right]^{\mathrm{a}}}\end{array}$ & $\begin{array}{c}\text { BET surface } \\
\text { area } \\
{\left[\mathrm{m}^{2} \mathrm{~g}^{-1}\right]^{\mathrm{a}}}\end{array}$ & $\begin{array}{c}\text { Average } \\
\text { Pore size } \\
{[\mathrm{nm}]}\end{array}$ \\
\hline $\begin{array}{c}\text { MS-7 } \\
\text { None }\end{array}$ & - & 0.92 & 866 & 6.5 \\
1 & 0.117 & 0.85 & 755 & 6.5 \\
2 & 0.212 & 0.70 & 571 & 6.3 \\
3 & 0.298 & 0.67 & 508 & 6.1 \\
4 & 0.370 & 0.58 & 438 & 5.9 \\
5 & 0.440 & 0.62 & 469 & 5.9 \\
\hline MS-10 & & & & \\
None & - & 1.3 & 561 & 10.7 \\
1 & 0.104 & 1.2 & 525 & 10.4 \\
2 & 0.199 & 1.2 & 500 & 10.2 \\
3 & 0.241 & 1.2 & 504 & 9.9 \\
4 & 0.316 & 1.1 & 490 & 9.5 \\
5 & 0.404 & 1.0 & 482 & 8.9 \\
\hline
\end{tabular}

${ }^{a}$ per weight of silica

which were calculated from the slopes for MS-7 and MS10 in Fig. 4, were 2.0 and $1.7 \mathrm{mmol} \mathrm{g}^{-1}-\mathrm{SiO}_{2}$, respectively. Thermogravimetric analysis of uncoated mesoporous

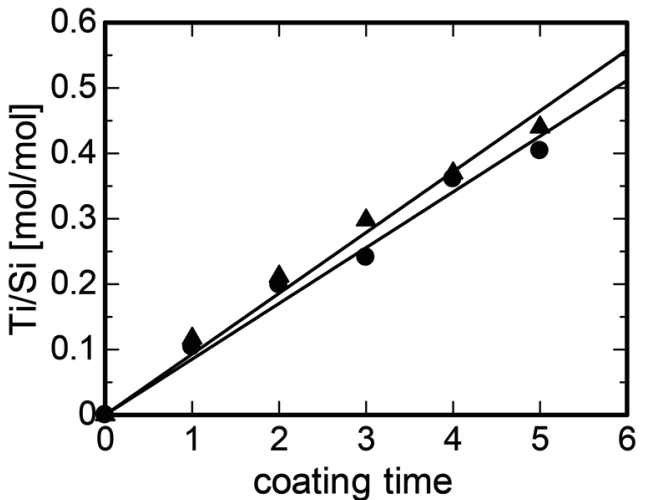

Fig. 4 Effect of the number of titania-coating times on $\mathrm{Ti} / \mathrm{Si}$ ratio for MS-7 (triangle) and MS-10 (circle)

silicas revealed that the amounts of silanol groups of MS-7 and MS-10 were 3.9 and $3.6 \mathrm{mmol} \mathrm{g}^{-1}-\mathrm{SiO}_{2}$, respectively. Considering that titanium tetraisopropoxide reacts with silanol groups on the pore walls, the titanium propoxide which was almost half amounts of the silanol groups are consumed for both MS-7 and MS-10. Increase of the titanium tetraisopropoxide amount (the mole ratio of $\mathrm{Ti}$ in titanium tetraisopropoxide to $\mathrm{Si}$ in mesoporous silica $=0.60$ ) 
for titania-coating of MS-10 did not increase Ti content in the coated MS-10, showing that the amount of the coating titania was saturated even when titanium tetraisopropoxide $(\mathrm{Ti} / \mathrm{Si}=0.30)$ was used, i.e. all silanols reacted with titanium isopropoxide at one coating step. These results indicate that one titanium propoxide molecule is linked with two Ti-O-Si bonds on average and that two unreacted isopropyl groups are converted to two hydroxyl groups, which react with one or two titanium propoxide molecules at the next coating. There was possible to link one titanium propoxide molecule to one hydroxyl group on the surface. Assuming that the single bond linkage was formed, at the next coating step one titanium propoxide molecule should react with three hydroxyl groups because the increments in titanium amount at each coating step were constant. Since in general it is difficult to form the linkage between one metal alkoxide and three hydroxyl groups on the surface, such linear correlation as shown in Fig. 4 might not be observed. Thus, we concluded that the most titanium propoxide molecules were linked to the mesopore surface with two Ti-O-M bonds (M: Si or Ti).

Fig. 5 shows maps of elemental analyses of silicon and titanium and TEM images of the sliced MS-7 coated with titania five times. Compared the distribution of silicon (Fig. 5(a)) to that of titanium (Fig. 5(b)), their distributions and the contrasts of the signals were the same, which shows that titania was uniformly distributed inside the mesoporous silica particles and that no large titania particles were formed out of MS. Moreover, we could not find titania nanoparticles inside the mesopores, as shown in Fig. 5(c) and (d).

Based on above various characterizations, the

(a)

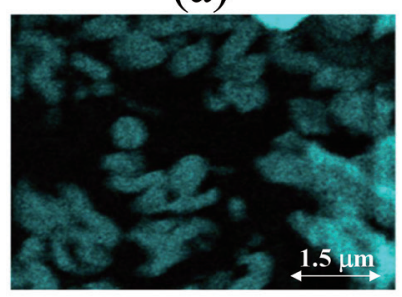

(c)

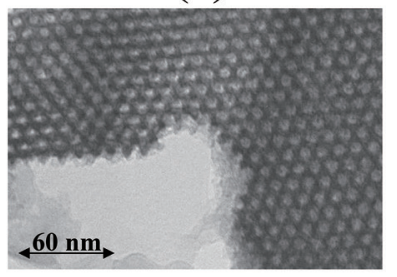

Fig. 5 Elemental analysis maps of silicon (a) and titanium (b) and TEM images (c) and (d) for MS-7 coated with titania five times.

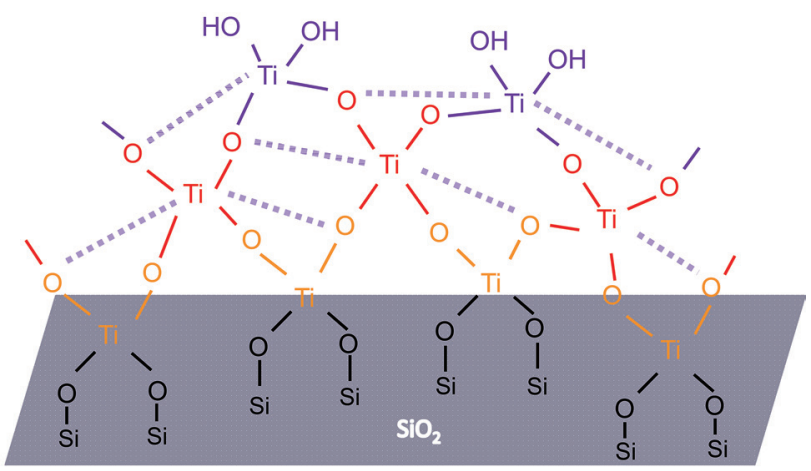

Fig. 6 Speculated structure of the silica walls coated with titania three times

speculated structure of the titania-coated silica walls could be proposed. Fig. 6 shows an example when titania coating was performed three times. At each coating step, the titanium isopropoxide was possibly linked to the walls with the two bonds. We speculated that large curvature of the pore walls might lead to ununiform coating of titania; MS-3 had small mesopores, whose curvature was much larger than those of MS-7 and MS-10. After three-time coating of MS-7, the pore size was smaller, possibly resulting in ununiform coating as mentioned before. When the pores with large curvature were coated with titania, a titanium tetraisopropoxide molecule could react with two silanols which were far from each other along pore circumference. Actually, the distances in a straight line from a point $1 \mathrm{~nm}$ away along pore circumference $(0.982 \mathrm{~nm})$ are smaller than that $(0.998 \mathrm{~nm})$ for MS-10. As a result, titanium distribution on silica walls may be uneven owing to formation of titania clusters inside the pores.

To examine the properties of titania layers, the amount of ammonia adsorbed on titania was measured for MS-7 and MS-10 using ammonia TPD analysis. Although it is generally accepted that Brønsted acid sites do not play an important role in HDS activity with Mo sulfide catalysts, it affects the dispersion of Mo sulfide particles through Mosupport interaction. Firstly it was confirmed that ammonia was not adsorbed on the MS itself and that pure titania (anatase) has the ability for ammonia adsorption owing to its acidity. The amount of adsorbed ammonia increased and then almost leveled off with an increase of coating time (Fig. 7). This suggests that mesopore wall was almost coated with titania layers after three-time coating.

The results of UV-Vis analysis of the coated silica also suggest that three times of titania coating was necessary to coat the whole walls with titania. Fig. 8 shows UV-Vis spectra of titania-coated MS-7 and MS-10. In the spectra of the samples coated once, the absorption wavelength was low, because titanium atoms were isolated 


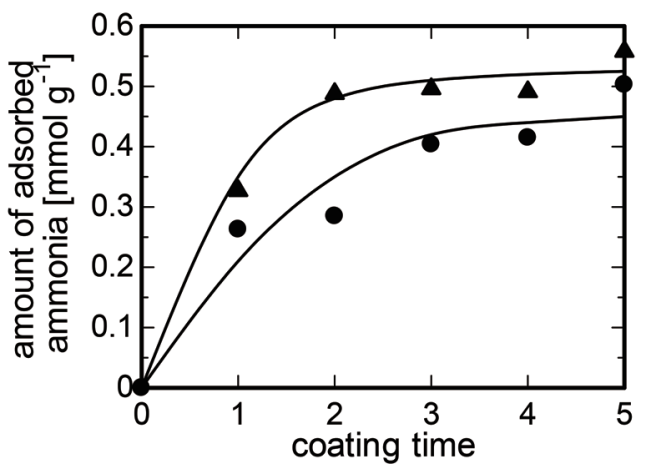

Fig. 7 Effect of coating time on the amount of adsorbed ammonia for MS-7 (triangle) and MS-10 (circle)

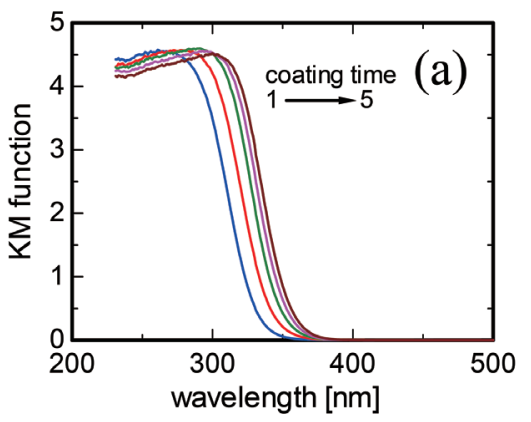

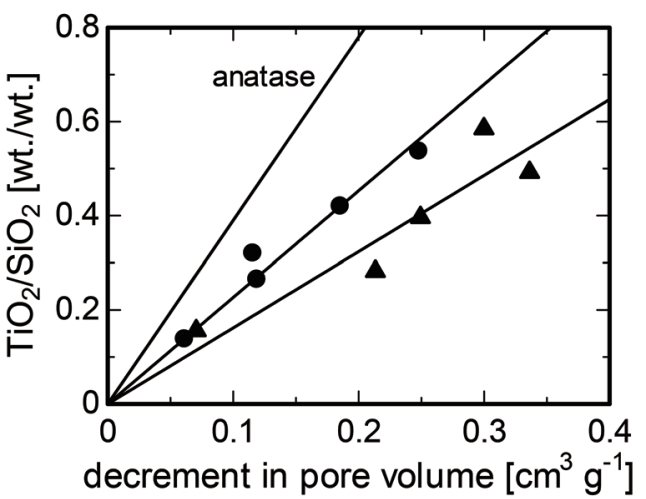

Fig. 9 Correlation between the decrement in pore volume per gram of silica and the weight ratio of titania to silica: MS-7 (triangle) and MS-10 (circle)

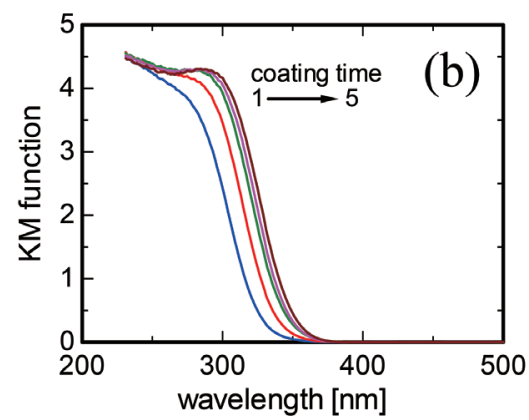

Fig. 8 UV-Vis spectra of titania-coated MS-7 (a) and MS-10 (b)

on the silica walls ${ }^{13}$. With the coating time, the wavelength increased and after three-time coating the absorption wavelength was hardly changed. This implies that Ti-OTi bonds were formed and that properties of titania layers possibly became similar to those of bulk titania after threetime coating.

Density of titania layers was calculated with the data from elemental analysis and nitrogen adsorption-desorption. Fig. 9 shows correlation between the decrement in pore volume per gram of silica from the uncoated mesoporous silica and the weight ratio of titania to silica. The decrement means the volume of the loaded titania, because the loaded titania was inside the mesopores. Thus, the slope means the density of the loaded titania. The slope of bulk anatase reported in the literature is also shown in Fig. 9. It is clear that the densities of titania in MS-7 and MS-10 were lower than that of anatase. Also significant peaks due to anatase were not observed in XRD charts for both samples. These results revealed that the loaded titania was amorphous. It should be noted that the density of titania in MS-10 was larger than that in MS-7. As described above, the amount of silanol groups of the uncoated mesoporous silica determined the amount of loaded titania. The densities of silanol groups on the pore walls of MS-7 and MS-10 were 4.5 and $6.6 \times 10^{-6}$ mol $\mathrm{m}^{-2}$, respectively, causing different densities.

\subsection{Coating mesopore walls of DMC-treated} mesoporous silicas with titania layers

From the aspect of usage of titania-coated mesoporous silicas as supports for hydrodesulfurization catalysts, mesoporous silica with three-dimensional pore network was more suitable for highly active catalysts than one-dimensional mesoporous silicas. Among three MSs with different pore sizes, MS-7 was selected for the DMC treatment since MS-7 had a higher surface area than MS-10. As mentioned above, three-time coating of MS-7 resulted in uniform coating. Therefore, titania coating of DMC-treated MS-7 was carried out three times. Fig. 10 shows the isotherms and the pore size distribution of DMCtreated MS-7 with and without titania layers. After DMC treatment, pore volume increased owing to an increase of silica wall density, along with an increase of pore size. Coating with titania decreased pore size. The isotherm of DMC-treated MS-7 with titania layers indicates that the pore walls were uniformly coated with titania. The specific surface area of the DMC-treated MS-7 with titania was $590 \mathrm{~m}^{2} \mathrm{~g}^{-1}$.

\subsection{Hydrodesulfurization with Mo catalysts}

The DBT-HDS activities for Mo/MS-7 with and without titania coating are listed in Table 2. In this reaction, 

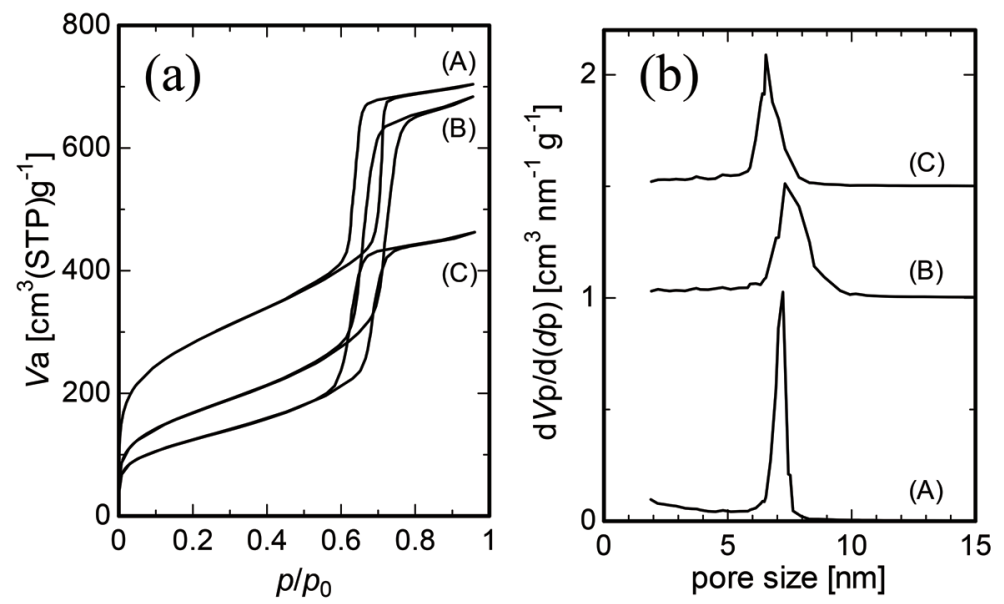

Fig. 10 Nitrogen adsorption-desorption isotherms (a) and pore size distributions (b) for MS-7 (A), DMC-treated MS-7 (B) and DMC-treated MS-7 coated with titania three times (C)

selectivity for biphenyl was more than $98 \%$, indicating that HDS of DBT is dominated by direct desulfurization route in this condition. It was observed that the DBT conversion was slightly decreased by titania coating. It is generally accepted that the addition of titania into the support in the form of complex oxide enhances the HDS activity ${ }^{21}$. The reason for this enhancement is not clear, but there have been some explanations as follows: (1) $\mathrm{MoS}_{2}$ cluster becomes smaller and (2) $\mathrm{MoO}_{3}$ is more easily reduced to $\mathrm{MoS}_{2}$. Both (1) and (2) lead to an increase of active sites. Also, (3) titania changes the interaction between $\mathrm{MoS}_{2}$ cluster and the support suitable for HDS reaction. In the case of our supports, titania exists on silica as a layer, thus it might be difficult and complicated to understand the results in Table 2. In order to understand it, however, TEM measurements were performed for the catalysts after presulfurization; we could not observe a significant difference in the size and the number of layer of $\mathrm{MoS}_{2}$ among the samples examined. To obtain information on the interaction between $\mathrm{MoS}_{2}$ cluster and the support, and to clarify the contribution of titania to reaction pathway for DBT species, naphthalene HYD was carried out and the results are summarized in Table 3 . It is

Table 2 Effect of titania coating on HDS of DBT

\begin{tabular}{lcc}
\hline \multicolumn{1}{c}{ Catalyst } & Coating times & Conversion $[\mathrm{mol} \%]$ \\
\hline Mo/MS-7 & 0 & 17.3 \\
Mo/MS-7/Ti(1) & 1 & 14.9 \\
Mo/MS-7/Ti(5) & 5 & 14.2 \\
\hline
\end{tabular}

Table 3 Effect of titania coating on HYD of naphthalene

\begin{tabular}{lcc}
\hline \multicolumn{1}{c}{ Catalyst } & Coating times & Conversion $[\mathrm{mol} \%]$ \\
\hline Mo/MS-7 & 0 & 9.8 \\
Mo/MS-7/Ti(1) & 1 & 15.9 \\
Mo/MS-7/Ti(5) & 5 & 21.2 \\
\hline
\end{tabular}

apparent that HYD activity to aromatics was increased by the titania coating, indicating the change of the interaction. Unfortunately, this increase of HYD activity did not affect the HDS activity because the direct removal of sulfur is the main route rather than the hydrogenation route for DBTHDS ${ }^{28}{ }^{29}$. Although the reason why the HYD activity to aromatics was increased by the titania coating is uncertain at moment, Ji et al. also found that $\mathrm{MoS}_{2}$ supported on alumina-stabilized titania shows higher HYD activity for tetralin than that supported on alumina ${ }^{30}$. They attributed the cause of high HYD activity of titania supported $\mathrm{MoS}_{2}$ catalysts to the difference of interaction between the sulfide phase and the support.

Table 4 shows the effect of both titania coating and three-dimensional pores on HDS of 4,6-DMDBT. For MS7 , the conversion was significantly increased from 7.4 to $18.2 \%$ by the titania coating. For MS-7(DMC) with threedimensional pores, the conversion was also gained from 30.3 to $39.3 \%$ by the titania coating. These results indicated that titania coating is useful to enhance the HDS activity for 4,6-DMDBT, in contrast to that for DBT. The aromatic HYD plays an important role for the HDS of 4,6-DMDBT ${ }^{31}{ }^{32}$. Thus the increase of the HYD activity (see Table 3) by the titania coating can be considered to enhance the HDS activity. Relating to the effect of three-dimensional pores,

Table 4 Effect of titania coating and three-dimensional pores on HDS of 4,6-DMDBT

\begin{tabular}{lcc}
\hline Catalyst & Coating times & Conversion [mol\%] \\
\hline Mo/MS-7 & 0 & 7.4 \\
Mo/MS-7/Ti(3) & 3 & 18.2 \\
Mo/MS-7(DMC) ${ }^{\text {a }}$ & 0 & 30.0 \\
Mo/MS-7(DMC) ${ }^{\text {a/Ti(3) }}$ & 3 & 39.3 \\
\hline
\end{tabular}

a MS-7 treated by DMC to form three-dimensional pores 
the HDS conversion for MS-7 was significantly increased from 7.4 to $30.3 \%$. This implies that the pore size of $7 \mathrm{~nm}$ with two entrances (or exits) is insufficient for the diffusion of 4,6-DMDBT. Also for the titania coated MS-7/Ti(3), the increase in HDS conversion was observed from 18.2 to $39.3 \%$ by creating the three-dimensional pores. These results strongly revealed that the formation of threedimensional pores is useful in the HDS of light gas oil which contains refractory sulfur compounds such as 4,6-DMDBT.

\section{Conclusions}

The coating of mesoporous silica with titania was carried out under thoroughly dried circumstances in the preparation. The formation of uniform titania layer depended on the pore size of MS; the larger pore size was more preferable to achieve the uniform titania layer. According to characterization of titania coated MS with various analyses, it was found that one titanium isopropoxide molecule was linked with two Ti-O-Si bonds and we proposed the mechanism of the titania layer formation.

Various MSs were use as the support of HDS catalyst. The titania coating of MS increased the HDS activity for 4,6-DMDBT HDS, while positive effect was not observed for DBT HDS. This activity increase was due to the change of the interaction between $\mathrm{MoS}_{2}$ and support, that is, HYD ability was improved and thus contributed to show a high HDS activity, in good agreement with the result from naphthalene HYD. Furthermore, we clarified that the formation of three-dimensional pore was useful to the reactant diffusion, resulting in a very high HDS activity.

\section{References}

1) Chen, X.; Mao, S. S., Chem. Rev., 107, 2891-2959 (2007)

2) Primo, A.; Corma, A.; García, H., Phys. Chem. Chem. Phys., 13, 886-910 (2011)

3) Stone, Jr., V. F.; Davis, R. J., Chem. Mater., 10, 1468-1474 (1998)

4) Wang, Y. Q.; Tang, X. H.; Yin, L. X.; Huang, W. P.; Hacohen, Y. R.; Gedanken, A., Adv. Mater., 12, 1183-1186 (2000)

5) Wei, L.; Wu, Z.; Wang, J.; Elzatahry, A. A.; Zhao, D., Chem. Mater., 26, 287-298 (2014)

6) Assaker, K.; Carteret, C.; Lebeau, B.; Marichal, C.; Vidal, L.; Stébé, M.-J.; Blin, J.-L., ACS Sustainable Chem. Eng., 2, 120-125 (2014)

7) Hossain, M. K.; Koirala, A. R.; Akhtar, U. S.; Song, M. K.; Yoon, K. B., Chem. Mater., 27, 6550-6557 (2015)

8) Kresge, C. T.; Leonowicz, E. M.; Roth, W. J.; Vartuli, J. C.; Beck, J. S., Nature, 359, 710-712 (1992)
9) Zhao, D.; Feng, J.; Huo, Q.; Melosh,Q., Fredrickson, N.; Chmelka, B. F.; Stucky, D. G., Science, 279, 548-552 (1998)

10) Landau, M. V.; Vradman, Wang, X.; Titelman, L., Micropor. Mesopor. Mater., 78, 117-129 (2005)

11) Vradman, L.; Landau, M. V.; Kantorovich, D.; Koltypin, Y.; Gedanken, A., Micropor. Mesopor. Mater., 79, 307-318 (2005)

12) Perathoner, S.; Lanzafame, P.; Passalacqua, R.; Centi, G.; Schlögl, R.; Su, D. S., Micropor. Mesopor. Mater., 90, 347361 (2006)

13) Cozzolino, M.; Serio, M. D.; Tesser, R.; Santacesaria, E., Appl. Catal. A, 325, 256-262 (2007)

14) Yan, W.; Mahurin, S. M.; Overbury, S. H.; Dai, S., Chem. Mater., 17, 1923-1925 (2005)

15) Zhang, F.; Carrier, X.; Krafft, J.-M.; Yoshimura, Y.; Blanchard, J., New J. Chem., 34, 508-516 (2010)

16) Ramírez, J.; Macias, G.; Cedeno, L.; Gutierrez-Alejandre, A.; Cuevas, R.; Castillo, P., Catal. Today, 98, 19-30 (2004)

17) Ishihara, A., J. Jpn. Petrol. Inst., 51, 73-82 (2008)

18) Cecílio, A. A.; Pulcinelli, S. H.; Santilli, C. V.; Maniette, Y.; Teixeira da Silva, V., J. Sol-Gel Sci. Tech., 31, 87-93 (2004)

19) Kim, J. H.; Ma, X. L.; Song, C.S.; Lee, Y. K., Oyama, S. T., Energy Fuels, 19, 353-364 (2005)

20) Huang, W.; Duan, A.; Zhao, Z.; Wan, G.; Jiang, G.; Dou, T.; Chung, K.; Liu, J., Catal. Today, 131, 314-321 (2008)

21) Mendoza-Nieto, J. A.; Puente-Lee, I.; Salcedo-Luna, C.; Klimova, T., Fuel, 100, 100-109 (2012)

22) Morales-Ortuno, J. C.; Ortega-Dominguez, R. A.; Hernandez-Hipolito, P.; Bokhimi, X.; Klimova, T. E., Catal. Today, 271, 127-139 (2016)

23) Okamoto. M.; Fukukita, Y.; Mimura, N., Shokubai, 47, 461-463 (2005)

24) Suzuki, E.; Akiyama, M.; Ono, Y., J. Chem. Soc. Chem. Commun., 136-137 (1992)

25) Ono, Y.; Akiyama, M.; Suzuki, E., Chem. Mater., 5, 442447 (1993)

26) Kubota, T; Miyamoto, N.; Yoshioka, M.; Okamoto, Y., Appl. Catal. A, 480, 10-16 (2014)

27) Kubota, T.; Rinaldi, N.; Okumura, K.; Honma, T.; Hirayama, S.; Okamoto, Y., Appl. Catal. A, 373, 214-221 (2010)

28) Egorova, M.; Prins, R., J. Catal., 221, 11-19 (2004)

29) Song, H.; Wang, J.; Wang, Z.; Song, H.; Li, F.; Jin, Z., J. Catal, 311, 257-265 (2014)

30) Ji, Y.; Afanasiev, P.; Vrinat, M.; Li, W. Z.; Li, C., Appl. Catal. A, 257, 157-164 (2004)

31) Villalón, P. C.; Ramírez, J.; Cuevas, R.; Vázquez, P.; Castaneda, R., Catal. Today, 259, 140-149 (2015)

32) Yang, L.; Li, X.; Wang, A.; Prins, R.; Chen, Y.; Duan, X., J. Catal., 330, 330-343 (2015) 